\title{
Enfranchising Displaced Voters: Lessons from Bosnia-Herzegovina
}

\author{
LAUREN PRATHER and ERIK S. HERRON
}

\begin{abstract}
How can the designers and administrators of election rules balance the need to enfranchise voters with the need to ensure the integrity of the vote? This tension is particularly acute when large numbers of voting-age citizens are displaced from their permanent residences due to war, natural disaster, or other conditions. Our article addresses the challenges of enfranchising refugees and internally-displaced persons (IDPs) by assessing statutory and practical experiences of Bosnia-Herzegovina from 1996-2006. This article adds to the research on displaced voters by exploring the treatment of refugees and IDPs in election laws, the debate surrounding their inclusion, and by assessing the participation of refugees and IDPs in one country across many elections.
\end{abstract}

\section{INTRODUCTION}

$\mathbf{T}$ HE QUALITY of elections is measured not only by the extent to which the franchise is guaranteed and elections are impartially administered for the majority of voters, but also by accommodations to enfranchise voters who are marginalized in the polity. Election legislation in democratic states often includes special provisions to facilitate voting by citizens who are elderly, disabled, institutionalized, or living in remote locations. Due to conflicts, natural disasters, and other sources of dislocation, many countries also confront the challenge of voters displaced from their homes, and by extension, from their polling sites.

Enfranchising displaced voters-from victims of conflict in Afghanistan and Iraq to the

Lauren Prather is a Project Assistant at Jenner \& Block LLP. Erik S. Herron is Director of the Center for Russian, East European and Eurasian Studies and Associate Professor of Political Science at the University of Kansas.
New Orleans diaspora created by Hurricane Katrina-has been a critical concern for election administrators in developing and established democratic states, who face several challenges in implementing free and fair elections. The eligibility of voters must be confirmed, sometimes without documentation establishing identity or place of residence. Voters must be assigned to vote in particular districts-especially if elections are legislative and constituency-based-even though they may no longer be residents in those districts due to displacement. Special polling sites may need to be established to accommodate diaspora voters unable to return to their home districts. Moreover, voters must have access to information about relevant campaigns, even though they may not be present in the region. All of these arrangements must ensure that voters may cast secret ballots in a secure environment, free from violence and intimidation.

Perhaps nowhere in the world has more time, attention, and effort been directed to the 
problem of displaced voters than in BosniaHerzegovina (Manning and Antic 2003). ${ }^{1}$ Conflict in the Balkan region generated hundreds of thousands of refugees and internally displaced persons (IDPs), most of whom were from the territory of Bosnia. The evolution of Bosnia's electoral procedures, born out of bloody civil war in the 1990s and subsequent formal resolution through the Dayton Accords, provides lessons about the management of displaced voters and the difficulties of maximizing enfranchisement while minimizing opportunities for manipulation and fraud.

In the article, we assess the Bosnian experience and comment on its generalizability beyond the Balkans. The article is divided into three parts. First, we review extant literature on enfranchising special needs voters. Second, we discuss the case of Bosnia, outlining the election laws designed to meet the needs of displaced citizens and the process of developing an election law. Third, we address the evolution of these rules in several categories (barriers to registration and participation, access to information, and the maintenance of a secure environment promoting a free and fair contest), focusing on implementation. This section establishes the technical and logistical considerations necessary to ensure meaningful political participation of refugees and IDPs. This article adds to the research on displaced voters by exploring the treatment of refugees and IDPs in election laws and the debate surrounding their inclusion, and by tracking the participation of refugees and IDPs in one country across many elections.

\section{LITERATURE ON SPECIAL NEEDS VOTERS}

Scholarship on special needs voting generally addresses how voting technology, ballot design, and other features of election administration affect the ability of citizens to accurately cast ballots. The normative basis for accommodating voters who are elderly, disabled, confined to homes or institutions, precluded by employment from voting in-person, speakers of minority languages, or minorities by virtue of other economic, educational, and social factors is addressed in several sources (March and Olsen 1995, Dahl 2000, Hall 2003, Wall 2003). Governments are advised to facilitate voting by using mobile ballot boxes, special voting locations, early voting, and absentee voting (Wall 2003). Increasingly, voting via the Internet has been advocated as a potential solution to accommodate special voting needs (McGaley and Gibsen 2003, Mercurio 2003). ${ }^{2}$

But, discussions of accommodations for special needs voters often raise concerns about systematic error in elections introduced by manipulation and fraud, and the systems used to record votes. Because voters casting ballots under special conditions are often those who rely on the state for their well-being and are subordinate to agents of the state, they may be more vulnerable to coercion. Scholars have noted that special accommodations for voters, such as mobile ballot boxes and special voting locations, can contribute to vote theft (Sobyanin and Sukhovolskiy 1995), though other researchers downplay the likelihood of fraud in established democracies (Southwell and Burchett 1997). Analyses of ballot effects in the 2000 presidential elections in the United States demonstrated that ballot structure systematically affected the vote, artificially inflating support for one candidate over another (Brady et al. 2001; Wand et al. 2001; Brady et al. 2004). Moreover, several researchers note that some voting instruments are more likely to generate overvotes or otherwise misrepresent voters' intentions at the ballot box, especially among minority and elderly voters (Knack and Kropf 2003, Herron and Sekhon 2003, Tomz and Van Houweling 2003).

\footnotetext{
${ }^{1}$ For simplicity, Bosnia-Herzegovina will henceforth be referred to as Bosnia. Similarly, the Federation of Bosnia and Herzegovina will be referred to as the Federation. 2 Some scholarship has specifically addressed how certain categories of special needs voters may be accommodated. Goler and Selker (2006) evaluate reading disabled voters' ability to cast ballots accurately and Berinsky, Burns and Traugott (2001) analyze voting by mail-an approach conducive to increasing turnout of the homebound, elderly, or disabled. Also, in emerging democracies where security is in question, military and police forces are often asked to vote before election day in order to provide security on the day of elections (Graham 2006).
} 
Displaced voters present election administrators problems that encompass and extend the challenges presented by other special needs voters. ${ }^{3}$ The displaced are generally enfranchised through casting ballots at their home precincts, at specially designated precincts elsewhere in the country or internationally, or by casting a mail ballot (Lacy 2004, 12). The literature specifically addressing displaced voters is scarce, however, and focuses on the participation of refugees and IDPs in just one election (Roberts 2003). The most active contribution to the discussion of displaced voter accommodation has been made by non-governmental organizations, specifically the Participatory Elections Project (PEP) and its successor the Political Rights and Enfranchisement Strengthening Systems (PRESS) project. ${ }^{4}$ These projects have produced case studies and a list of relevant information about election issues for refugees and IDPs. ${ }^{5}$ In addition, the projects have produced a document containing recommended standard procedures for the inclusion of refugees and IDPs in elections (Fischer and Grace 2003). The need for more research onand international election standards addressing - the needs of refugees and IDPs is reflected in a statement made by the International Mission for Iraqi Elections on the January 2005 elections. They called the Out-of-Country Voting $(\mathrm{OCV})$ program a " . . s singular achievement, particularly since OCV is not a required practice, even in long-established democracies" $(2005,1)$. However, as noted above, managing the needs of displaced voters has been at the center of international and domestic efforts to establish post-conflict democratic standards in Bosnia.

\section{ENFRANCHISING THE DISPLACED IN BOSNIA-HERZEGOVINA}

Economic hardships and the fading hold of communism eventually led to the breakup of Yugoslavia into its constituent republics. ${ }^{6}$ Two republics, Croatia and Slovenia, made moves to secede in 1991. At the same time, Serbia looked to expand its borders to include ethnic
Serbs not already living within them. After Croatia and Slovenia broke away, Serbia engaged in a six-month war in Croatia that claimed thousands of lives. This war ended only with international recognition of Croatian statehood.

Bosnia's declaration of independence from the former Yugoslavia followed on March 3, 1992. Over the course of three years-1992 to 1995-Bosnian-Serbs and Bosnian-Croats, with external aid, launched an ethnic cleansing campaign (Kaldor 1999). The war devastated the economy, killed approximately 200,000, and severely damaged the social fabric of Bosnia's society. Groups-generally mono-ethnic-fled or were forced to flee as a result of the ethnic cleansing campaign. During the war, $60 \%$ of a pre-war population of 4.3 million was displaced: approximately 1.2 million refugees fled Bosnia and an additional 1 million were displaced inside Bosnia. ${ }^{7}$ As a result of the ethnic cleansing campaign, Bosnia's once multi-ethnic landscape was effectively partitioned between the three ethnic groups-Serbs, Croats, and Bosniaks (Dahlman and Tuathail 2005).

${ }^{3}$ Voluntarily itinerant or nomadic voters encounter some of the same difficulties of displaced voters and thus require similar accommodations. Elections in Afghanistan are a current example, where attempts to accommodate both itinerant and displaced voters have been used. An analysis of the 2005 Parliamentary and Provisional Council elections with some focus on the issues faced by itinerant and displaced voters can be found here: $<$ http://ec.europa.eu/external_relations/human_rights / eu_election_ass_observ/afghanistan/final_report.pdf $>$. ${ }^{4}$ PEP commenced in 2002 as a project directed by the International Organization for Migration (IOM) and funded by the US Agency for International Development (USAID). The project was completed in 2004. The PRESS project began in 2004 with a grant from USAID under the supervision of IOM. It was completed in June 2007.

${ }^{5}$ See $<$ http://www.geneseo.edu/ iompress/?pg=main. html $>$. In addition to the PRESS and PEP materials, researchers at IFES have produced a general document on refugee and IDP participation in elections (Lacy 2004). Another project directed by researchers at the Brookings Institution and Johns Hopkins University has focused on the electoral participation of IDPs in the OSCE region (Mooney and Jarrah 2005).

${ }^{6}$ Many scholars have assessed the causes and consequences of Yugoslavia's collapse. For some perspectives, see Bunce (1999) and Morton et al. (2004).

${ }^{7}$ Data are from the UNHCR Sarajevo web site: <http:// www.unhcr.ba/index.htm $>$. 
Eventually, the high costs of war prompted negotiations, managed by the international community (Cousens 2002). The warring parties reached and initialed an agreement at Dayton, Ohio, in November 1995 and signed a formal agreement in December. A NATO peacekeeping force (IFOR) and other international organizations such as the United Nations divided the task of implementing the peace accords. The NATO peacekeeping force was responsible for maintaining peace between warring military and paramilitary groups, while other organizations managed civil reconstruction, including elections (Daalder 2000).

The Dayton Peace Accords (DPA) provided a framework by which the international community could approach the issue of elections and deal with the massive population of displaced persons. The newly formed constituent parts of the country of Bosnia-the Federation of Bosnia-Herzegovina and the Republika Srpska-agreed that they would

... ensure that conditions exist for the organization of free and fair elections, inparticular a politically neutral environment; shall protect and enforce the right to vote in secret without fear or intimidation; shall ensure freedom of expression and of the press; shall allow and encourage freedom of association (including of political parties); and shall ensure freedom of movement (DPA 1995, 1).

NATO was responsible for keeping the peace, and the Organization for Security and Cooperation in Europe (OSCE) was given the responsibility of election implementation and oversight. The OSCE established the Provisional Election Commission to ensure compliance with the DPA and to create regulations facilitating free and fair elections.

\section{Elections and the right of return}

Article IV of the DPA's Annex 3 details the eligibility requirements for those wishing to participate in the elections. It extended suffrage to citizens 18 years or older who were listed in the 1991 census. Among the greatest challenges to administering elections in the territory was the displaced population. The DPA set forth the following rules for IDPs and refugees:

A citizen who no longer lives in the municipality in which he or she resided in 1991 shall, as a general rule, be expected to vote, in person or by absentee ballot, in that municipality, provided that the person is determined to have been registered in that municipality as confirmed by the local election commission and the Provisional Election Commission (DPA 1995, 1).

One of the more controversial aspects of this clause was the connection of political participation to return to one's former place of residence. The law states that by casting a ballot, a citizen confirms " ... his or her intention to return to Bosnia and Herzegovina. By election day, the return of refugees should already be underway, thus allowing many to participate in person in elections in Bosnia and Herzegovina" (DPA 1995, 1). Indeed, an entire section (Annex 7) of the DPA is devoted to refugees and IDPs. ${ }^{8}$ While the DPA indicates that the concern is with the return of refugees, this statement can also be extended to include IDPs.

Implementing the provisions provided in the DPA for refugee and IDP return was problematic. First, the return of property to the displaced did not happen expeditiously and was frequently the source of more conflict. The problem was so acute that by 2001 when Bosnia finally adopted its Permanent Election Law, provisions were made to prevent people from running for office or voting in the election if they still occupied property that was not their own (Election Law of $\mathrm{BiH}$ 2001). Second, the

\footnotetext{
${ }^{8}$ Article I of Annex 7 of the DPA states, "All refugees and displaced persons have the right freely to return to their homes of origin. They shall have the right to have restored to them property of which they were deprived in the course of hostilities since 1991 and to be compensated for any property that cannot be restored to them. The early return of refugees and displaced persons is an important objective of the settlement of the conflict in Bosnia and Herzegovina. The Parties confirm that they will accept the return of such persons who have left their territory, including those who have been accorded temporary protection by third countries" $(1995,1)$.
} 
article claims that all signatories will accept the return of the displaced. However, in the eastern part of the country the powerful Serbian nationalist parties blocked most repatriation attempts. Due to ethnic cleansing operations during the war, most IDPs attempted to return to an area where their ethnicity was the minority. Return was as unappealing to the returnees as to those who did not want them to re-settle in their former homes. Thus, although return was emphasized, the ability for refugees and IDPs to return was limited and return was sometimes dangerous. ${ }^{9}$

The initial paradox faced in 1996 by potential refugee and IDP voters-an expectation of return without security conditions supporting return-was confronted three years later by those debating the draft electoral law put forth by the OSCE. From 1996-2000, the OSCE administered elections based on the provisions of the DPA and other rules and regulations deemed necessary by the Provisional Election Commission. Recognizing the necessity of a formal election law, the OSCE and the Office of the High Representative for Bosnia-Herzegovina initiated the process in 1998. They presented a draft law to the Bosnian legislature in 1999. The key sticking point for the negotiating parties was whether or not the election law would include a provision that continued to allow displaced persons to choose their voting location (AIM Sarajevo 2000).

In the debate that followed, the Party of Democratic Action (SDA), a Bosniak nationalist party, and various public voices, objected to the right of the displaced to vote in one's previous or current residence. They did not want the new electoral law to encourage the displaced to vote in their current residences, believing that this would contribute to the formalization of increasingly distinct ethnic regions (AIM Sarajevo 2000). However, those who had drafted the law did not want to risk disenfranchising those who could not return to vote or who did not want to vote in an area in which they were an ethnic minority.

Despite the intense negotiations, the Bosnian parliament eventually passed a Permanent Election Law in August 2001. The Permanent Election Law transferred the electoral respon- sibilities from the OSCE to Bosnian governing bodies. The treatment of refugee and IDP voting rights was more detailed, though it remained controversial. While the OSCE had already implemented some of the new provisions, the election law codified them.

Article 19.8 of the Permanent Election Law deals exclusively with the issue of refugee and IDP voting. For the purposes of the 2001 Permanent Election Law, "displaced person" refers to an internally displaced person. It states,

A citizen of Bosnia and Herzegovina who is a displaced person and has the right to vote under this article, shall register depending on the voting option this person chooses, for the municipality where he or she had a permanent place of residence according to the last Census conducted by the State of Bosnia and Herzegovina, except in the case where this person can provide proof of a change of his or her permanent residence in accordance with the law, in the period from the last Census conducted by the State of Bosnia and Herzegovina until this person acquired status as a displaced person, or for the municipality where this person has current residence and provides proof that he or she has registered as a current resident at least six (6) months prior to the election day (Election Law of $\mathrm{BiH} 2001,37$ ).

The election law points out that a current residence is the residence occupied by the displaced person at the time of registration. However, this residence is acknowledged as temporary, to be used only until that person returns to his or her place of permanent residence. The section of Article 19.8 dealing with refugee accommodations has nearly the same wording. However, it does not mention current residence because refugees could not vote in their current residence. The Permanent Election Law codified practices already in progress, displeasing those in favor of ethnic reintegration.

\footnotetext{
9 By August 2000, minority movements were slight; only 360,000 of the more than one million Bosnian refugees had returned to Bosnia (Black 2001, 186).
} 
Other controversial provisions included a provision in Article $19.8^{10}$ that eliminated the right to vote in a current residence by persons occupying property that is not their own and Article $19.9^{11}$ that eliminated the right to run for office by persons who are occupying property that is not their own (Election Law of $\mathrm{BiH}$ 2001,37-38). Originally, the DPA had attempted to ameliorate the situation of improper residential occupation by calling for the Commission for Real Property Claims of Displaced Persons and Refugees to handle competing claims of property ownership. However, only 19 percent of the 225,000 claims that were filed had come to resolution by the year 2000 (Office of the High Representative 2000). Thus, as the new election law was being debated in 1999 and 2000, this issue was on the minds of the negotiators and ultimately was included in the Permanent Election Law. Table 1 below summarizes the issues faced by refugees and IDPs who are covered by the 2001 Permanent Election Law.

\section{April 2006 amendments to the Permanent Election Law}

Following the 2004 elections, new proposals emerged to modify the existing law. The Association of Election Officials in Bosnia and Herzegovina developed recommendations in 2005 that were subsumed under the Council of Europe's European Commission for Democracy through Law, better known as the Venice Commission. The Venice Commission helped to formulate the draft law that eventually became Bosnia's Permanent Election Law and put forth new draft amendments in March 2006. The primary change affecting refugees and IDPs as well as the general population was a move from active to passive registration. The new process is described in Chapter 3 of the amended election law.

In brief, the new process requires citizens to apply for an ID card with the Citizen Identification Protection System. Those citizens who apply for the ID card are automatically added to the Central Voter Register, eliminating the need to register before each election. Citizens will only need to update their information as it becomes necessary (European Commission for
Democracy through Law 2006). However, this new process does not simplify registration for refugees and IDPs. Refugees must still apply to vote by mail or absentee before each election. IDPs must apply to vote in either their place of current residence or their 1991 municipality (European Commission for Democracy through Law 2006).

\section{REVIEW OF ELECTIONS AND THE POLITICAL ENVIRONMENT IN BOSNIA-HERZEGOVINA}

Since the end of active combat, seven elections have been conducted in Bosnia for national and local offices (see Table 2). The institutional rules governing these elections have reflected the country's contentious politics and the challenges of satisfying the demands of multiple, antagonistic, constituencies. ${ }^{12}$

Bosnia's executive branch is divided into three seats; one dedicated to a representative of each of the main ethnic groups. Voters in the Federation select the Bosniak and Croat members of the executive branch; voters in Republika Srpska select the Serb representative. This unusual method of representation in the exec-

10 The provision states: "The citizen of Bosnia and Herzegovina who is occupying a house or an apartment for which s/he does not have an ownership or occupancy right, while an enforcement document is issued by a competent court or administrative authority on the restitution of a house or an apartment, or CRPC decision, has no right to vote in the place of current domicile, until s/he abandons real estate property owned by others, and may register to vote only in the municipality where s/he had the permanent residence in accordance to the last Census in Bosnia and Herzegovina" (Election Law of BiH 2001, 37).

11 The provision states: "No person may stand as a candidate, hold an elected mandate or an appointed office, who fails to vacate real estate property which is owned by a refugee or displaced person, or fails to leave an apartment where a refugee or displaced person has an occupancy right, or failed to leave an apartment, which is under the administration of the municipal administrative authority responsible for housing or responsible body of the RS Ministry of Refugees and Displaced Persons for use as alternative accommodation. ..." (Election Law of $\mathrm{BiH} 2001,38)$.

12 For an assessment of institutional decisions in Bosnia and how they reflect different theoretical approaches to conflict resolution, see Casperson (2004). 
Issue (Section of 2001 Law)

Right to vote from abroad (Article 1.5, Article 3.4, Article 3.13)

Freedom of Movement (Article 1.11)

Registering to vote (Article 3.4, Article 3.11, Article 3.13)

Right to vote in 1991 residence (Article 5.12)

Identification documents required (Article 5.12)

Name absent from Central Voters Register because one registered out of country and has now returned (Article 5.18)

Right to vote by mail (Article 5.21)

Validity of mail vote (Article 5.28)

Right to vote in permanent OR current residence for IDPs (Article 19.8)

Right to vote in permanent OR new permanent residence for refugees (Article 19.8)

Occupancy right and voting (Article 19.8)

Cessation of the special rights given to refugees and IDPs (Article 19.8)

Protection of property rights (Article 19.9)

\section{Legal Provision*}

A citizen residing abroad, either temporarily or as a refugee, has the right to register and vote in the municipality where he/she is registered as a permanent resident.

Competent authorities will ensure that no obstacles impede freedom of movement of candidates, supporters and voters during the entire electoral process.

The Election Commission... will establish... the method and procedure for the entering of voters into the Central Voters Register who... reside and submit an application for registration from outside the territory of Bosnia... The citizen must provide proof of residence... Once registered, the citizen must submit a confirmation before each subsequent election. A citizen who returns before the registration deadline must update his/her status; if after the deadline, he/she must vote by tendered ballot.

A voter must cast his/her ballot at the Polling Station where he/she is registered. However, if the voter has the right according to the law to vote in his/her 1991 municipality, the voter may vote at an absentee polling station.

The voter shall provide one of the following that contains a photo: identification card; passport; driver's license; military identification card; a valid identification document issued by a host country; or a refugee card issued by a host government or other international agency.

If one returns to Bosnia after having registered to vote from abroad and cannot find his/her name on the final voters' register, then the voter will be allowed to vote by tendered ballot, will add his/her name to a special form to be signed by the voter, and will have his/her identification retained until he/she returns the tendered ballot in a sealed envelope.

A citizen who has the right to vote and is abroad may vote by mail. The Election Commission shall regulate this process.

The ballot must be delivered to the Election Commission by postal authorities by a time and date to be determined by the Election Commission and postmarked by election day. The voter must be properly registered to vote by mail, seal the envelope and provide a copy of the identification documents required in Article 5.12.

A citizen who is a displaced person has the right to register and to vote in either his/her permanent residence according to the last Census unless he/she can provide proof that this permanent residence has changed. A citizen who is a displaced person can also choose to vote in his/her current residence provided that he/she registered as a current resident at least six months prior to the election.

An enfranchised citizen who is a refugee may register and vote in the municipality where he/she has permanent residence according to the last Census, unless he/she can provide proof that this permanent residence has changed.

A citizen of Bosnia who occupies a house while an enforcement document is issued, may not vote in the place of current domicile, until he/she abandons the property owned by another. He/she may only vote in the municipality where he/she has permanent residence in accordance with the last Census.

The High Representative will determine when the special rights of refugees and IDPs will end. The following will be considered when determining the date of cessation: status of implementation of property laws and number of persons registered as IDPs.

No person may stand as a candidate or hold an elected position who fails to vacate the real estate property owned by a refugee or IDP, or an apartment where a refugee or IDP has an occupancy right, or an apartment managed by the RS Ministry of Refugees and Displaced Persons. A deadline must be specified by either an administrative decision, an enforcement decision pursuant to a CRPC certificate, or a court decision. This person must be given at least 30 days notice.

\footnotetext{
*all 2001 provisions taken from Election Law of BiH (2001).
} 
TAble 2. Elections in Bosnia, 1996-2006

\begin{tabular}{ll}
\hline Year & \multicolumn{1}{c}{ Election } \\
\hline $2006^{*}$ & National Parliament, Collective Presidency, and Local Offices \\
2004 & Local Offices \\
2002 & National Parliament, Collective Presidency, and Local Offices \\
1998 & National Parliament, Collective Presidency, and Local Offices \\
1997 & National Assembly (Republika Srpska) \\
1997 & Local Offices \\
1996 & National Parliament, Collective Presidency, and Local Offices \\
\hline
\end{tabular}

*The elections in 2006 were the first contests since the wars of Yugoslav secession to be administered solely by the authorities of Bosnia and Herzegovina. Previous elections were managed or overseen by international organizations.

utive provides each ethnic group some direct representation, and encourages, at least in principle, the pursuit of moderate policies.

Institutional efforts to provide descriptive representation are also present in the rules for legislatures. Representatives to legislative bodies: the House of Representatives for Bosnia, ${ }^{13}$ as well as local assemblies in the Federation, Republika Srpska, cantons and at the municipal level, are selected using the mechanics of proportional representation. ${ }^{14}$

The central issue in Bosnian politics is ethnic security (NDI 1996, ICG 1998), and parties appealing to nationally / ethnically-defined constituencies have dominated the post-war Bosnian electoral scene. ${ }^{15}$ These parties gain electoral support under the assumption that they can best safeguard the power and security of their ethnic brethren. While these parties have performed reasonably well in post-conflict elections, their vote share has declined over time (Casperson 2004, Manning 2004b).

Some parties, such as the Serbian Democratic Party (SDS) in 1996, went so far as to use secessionist rhetoric to galvanize their followers (OSCE 1996a). Formal controls were added to control inflammatory language for the 1998 elections. In order to register candidates for the 1998 elections, parties were required to submit party platforms on four main issues: refugee returns, minority rights, economic and social affairs. Provocative language in these platforms or other campaign media could be punished by the elimination of candidates from party lists. In general, the parties' greatest concerns in the 1998 elections were the economy, security, return of refugees, and the increasing number of young people leaving the country (OSCE 1998).
In addition to stricter controls on campaign language, the international community strengthened programs aimed at providing technical assistance to opposition parties (ICG 1998). ${ }^{16}$

While approval for nationalist parties has declined over time, they continue to enjoy significant support. ${ }^{17}$ However, alternative parties have made progress. In the 2002 elections, a wide range of parties and coalitions contested seats (Manning 2004b). These elections were

13 Members of the House of Peoples are indirectly selected (OSCE 2007).

14 The specific rules governing the elections are complex (using multi-member constituencies and compensatory seats) and have changed over time. For detailed discussions of various elections in Bosnia, see: OSCE reports (1997a, 1998, 2003, 2005, 2007), Pugh and Cobble (2001), Burwitz (2004), and Manning (2004b).

${ }^{15}$ Parties such as the Party of Democratic Action (SDA) (Bosniak), Croatian Democratic Union (HDZ), and Serbian Democratic Party (SDS) have been the main post-war competitors (Pugh and Cobble 2001; Bojkov 2003; Manning 2004b). Also see Manning 2004a for a discussion of how groups engaged in conflict evolve in post-war politics. But, some change to the party system occurred by the 2006 elections. Less narrowly-defined political organizations emerged (such as the Party for Bosnia and Herzegovina, led by a Bosniak, but considered to be more moderate) and competition increased within ethnic communities. The leading Serb party (SDS) faced challenges from the Alliance of Independent Social Democrats, and competition for leading Bosniak and Croatian parties also increased (OSCE 2007).

16 The National Democratic Institute is one of the main non-governmental organizations (NGOs) working with opposition parties in Bosnia. Read their 1996 plan to strengthen these political parties for a summary of this effort. < http://www.accessdemocracy.org/library/379_ bo_strengthpo96.pdf $>$.

17 In 2000, SDS showed resurgence and in the same year, Croats in Bosnia overwhelmingly voted for the nationalist Croat party (ICG 2000). However, a drop in voter turnout among Bosnian-Croats may have indicated displeasure with that party, the HDZ. 
also the first to be administered on the basis of the Permanent Election Law and with unprecedented involvement by Bosnian officials. The administration of the election was largely seen as a success (Manning 2004b), but the continued election of nationalist parties did little to advance the integration process (Bojkov 2003).

More recently, Bosnia conducted its first selfadministered elections in 2006. Some of the most significant competition involved parties representing the same ethnicity (OSCE 2007). ${ }^{18}$ The Party of Democratic Action, the party that has received substantial support in the Bosniak community, tried to impart a more multiethnic image in the 2006 election campaign (OSCE 2007), though ethnic politics seem to have become entrenched (Lippman 2006). Political competition focused on ethnic security issues has done little to alleviate impediments to refugee and IDP participation and has contributed to an environment in which they and the electoral system have been open to manipulation.

\section{IMPLEMENTATION OF ELECTION LAWS}

The previous sections noted how formal institutional requirements proposed to accommodate refugee and IDP voters and described the political background against which this accommodation had to occur. This section addresses the implementation of the formal requirements on the ground. While official mechanisms were codified to enfranchise voters, these mechanisms did not always smoothly function. We address four areas of implementation: procedural requirements for registration and voting, access to information for citizens to cast meaningful ballots, security arrangements to ensure that voters were not intimidated, and efforts to undermine manipulation and fraud at the polls. While this section will not provide an exhaustive review of all elections, it will comment on how accommodations for displaced voters have evolved.

\section{Procedures}

The process of voter registration and the accuracy of final voter lists has been a consistent problem in nearly all of Bosnia's post-Dayton elections. An accurate and transparent voter list is one of the best ways to maintain the trust in an electoral system while protecting the system from attempts at fraudulent voting. ${ }^{19}$ Problems associated with voter registration for the displaced include lack of appropriate documentation, lack of information concerning how and where to register, and lack of time to complete the required registration steps.

Rules about documentation establishing a voter's current residence were tightened during the 1997 municipal elections (OSCE 1997b) to counter widespread manipulation of voter residency claims during the 1996 elections (see below). The new rules particularly affected voters in the Brcko district where 3,200 voters were turned away due to improper documentation. The OSCE acknowledged in its final report on the 1997 elections that the documentation requirement may have been too restrictive and displaced persons who legitimately had current residence were disenfranchised (1997a) ${ }^{20}$ The passage of the Permanent Election Law in 2001 saw no change to the documentation requirements.

By the 2004 elections, the displaced continued to be disenfranchised because of registra-

18 The dominant three nationalist parties faced greater intra-ethnic competition with significant consequences. For example, the HDZ lost the Croat seat in the Presidency to a rival Croat party.

19 This sentiment is echoed in several of the documents relating to standards for free and fair elections put forth by various intergovernmental organizations (IGOs) and NGOs. For example, the OSCE notes: "[f]rom recognition of the individual right to vote flows the necessity of voter registration machinery without which, in many cases, there would be no effective exercise of the right. Protection of the right to vote requires the establishment and maintenance of true and accurate voter registers" (OSCE/ODIHR 2002, 13).

${ }^{20}$ Both the United Nations Office of the High Commissioner for Human Rights 1951 Convention on Refugees and the Guiding Principles on Internal Displacement (1998) make it imperative that governments provide refugees and IDPs with appropriate documentation to prove their status as citizens before the law. Principle 20 of the Guiding Principles on Internal Displacement states: "Every human being has the right to recognition everywhere as a person before the law... . To give effect to this right for internally displaced persons, the authorities concerned shall issue them all documents necessary for the exercise and enjoyment of their legal rights . . . without imposing unreasonable conditions, such as requiring the return to one's area of habitual residence in order to obtain these or other required documents" (1998, 10-11). 
tion rules. The OSCE report on the 2004 elections comments that for out-of-country voting, voters needed to "post by 2 October a barcoded instruction letter, a copy of an identity document, and evidence of their voter registration with their ballot papers in a secrecy envelope" (OSCE 2005, 22-23). This requirement proved to be problematic; on election day, eleven percent of the out-of-country voters were disqualified due to improper documentation. While electoral authorities must use documentation as a preventative tool to ward off fraud, strict measures may disenfranchise refugees and IDPs with a legitimate right to vote.

In 2006, despite the passage of amendments changing registration from active to passive, voters still encountered registration problems, particularly voters who did not apply for the ID card now required for registration. However, the Central Election Commission decided to err on the side of inclusion by allowing voters who applied after the deadline to vote by tendered ballot. Thus, while the election law contains strict documentation requirements, the Central Election Commission interpreted the rules for the 2006 election in favor of enfranchisement (OSCE 2006). Additionally, passive registration was not available to out-ofcountry voters and refugees, who were required to apply several months before the election. $^{21}$ IDPs were required to identify where they would vote-in the previous or current residence-by the same deadline. The Central Election Commission permitted 3,300 voters who lost IDP status after the deadline to retain voting rights provided to IDPs for the 2006 general election (OSCE 2007).

In addition to the documentation requirements, refugees and IDPs often lacked adequate lead time to receive information about voting. Refugees and IDPs need this time to gather the required materials and then either travel to absentee polling stations or send their vote by mail. A report by the International Crisis Group (ICG) on the 1996 elections points out that the under-funding of the OSCE election administration caused delays to the beginning of the registration process (1996b). In June, only three months before the September 14 elections, registration opened for the 900,000 refugee vot- ers in over 64 countries. To register this large number of refugees in such a short period of time proved to be a nearly impossible task. ${ }^{22}$ This problem was eventually remedied by the OSCE through amendments to the election law changing the registration timeline.

The third issue with voter registration is the quality of the final voter list. Given the complexity of the registration process for refugees and IDPs, it is not surprising that many displaced voters have, at times, not found their names on the final voter list on election day. This problem was particularly severe during the 1996 elections (OSCE 1996a). As previously noted, many refugees were disenfranchised due to an unorganized and hurried registration period. IDPs, however, encountered greater challenges in the act of voting. In the 1996 elections, the OSCE set up remote polling stations close to the Inter-Entity Boundary Line as well as a transportation network meant to help IDPs who wanted to vote in the precincts covering their 1991 residences. However, fifty percent of all voters in the Federation could not find their names on the final voters list, according to the OSCE. In Republika Srpska, thirty-six percent could not find their names on the final voter list (OSCE 1996b). This complication was particularly troublesome for IDPs who had crossed the Inter-Entity Boundary Line. Due to security concerns, these voters were told not to leave the premises of the remote voting stations. But, the only way to obtain permission to vote was to leave the stations; voters who were not on the final voters list were supposed to travel to the Local Election Commission to obtain a certificate and return to the precinct to cast a ballot. Thus, thousands of IDP voters were disenfranchised, though the OSCE claims that this disenfranchisement did not affect the overall outcome of the elections. ${ }^{23}$ Problems with the final voter lists have continued to af-

\footnotetext{
${ }^{21}$ The deadline was July 18, 2006.

22 According to the International Crisis Group report, the Bosnian Embassy in Vienna estimated that over 200,000 refugee voters could not be registered in time and were thus disenfranchised (1996b).

${ }^{23}$ However, the OSCE notes that had the municipal level election been carried out as had been originally planned, this disenfranchisement would have affected the local results (1996b).
} 
fect refugees, IDPs, and other voters in Bosnia; in $55 \%$ of monitored precincts in the 2006 elections, OSCE observers witnessed voters denied a ballot due to some discrepancy on the final voter list (OSCE 2007, 20).

The final procedural issue that disenfranchised many of Bosnia's displaced was the administration of absentee polling stations. The OSCE set up absentee polling stations in 1997 within Bosnia for IDP voters who wished to cast their ballots in their permanent residence, as opposed to their current residence, but could not make the journey. Likewise, for refugee voters, absentee polling stations were also set up for refugee voters who were able to get to them and for whom this was a more favorable option than voting by mail (OSCE 1997a). Many of the problems experienced by refugees and IDPs at absentee polling stations are instructive for administrators working to enfranchise displaced voters. For example, the OSCE reported that many absentee polling stations were too small, resulting in both security issues for those waiting to go inside, and frustration when the conditions inside undermined voters' ability to cast a ballot. Also, the lack of materials resulted in many voters not having the chance to vote in Bosnia as well as in polling stations for refugees in Croatia and the Federal Republic of Yugoslavia (OSCE 1997a).

In 2006, the OSCE noted problems associated with mail-ballots, particularly inconsistent decisions by the Central Election Commission. In one case, a Croatian organization sent a package of completed ballots from out-of-country voters in violation of appropriate procedures. The Central Election Commission returned the ballots to voters, allowing them to re-send their votes instead of declaring them invalid. In addition, the Central Election Commission decided after the elections to invalidate 349 ballots ostensibly from out-of-country voters but bearing local postmarks (OSCE 2007, 7).

\section{Information access}

Refugee and IDP isolation from the home community complicates their acquisition of information about the voting process (how/ where/when to vote) and about the parties and candidates in competition. While election ad- ministrators have greater responsibility for disseminating information about the former and candidates the latter (Fischer and Grace 2003), access to both categories of information is critical for the implementation of free and fair elections. ${ }^{24}$ Election reports suggest that inadequate access to information about election procedures is a more acute problem than access to information about parties and candidates. ${ }^{25}$

Because sixty percent of the population was displaced at the time of the first elections, parties and candidates had a strong incentive to disseminate information to refugees and IDPs. But, while information provision can be benign, it also manifested sinister characteristics; information that was given to the displaced (especially in 1996) was often meant to intimidate IDPs into selecting a certain municipality in which to vote.

Violations of the rights of the displaced to information were observed by various organizations in several elections. In 1996, the OSCE observed that several of the provisions in the Copenhagen standards for free and fair elections were not met, particularly unimpeded access to the media (Conference for Security and Cooperation in Europe 1990, 6). Local election observers from the Centers for Civic Initiatives and the NGO Network of $\mathrm{BiH}$ (2000), noted problems with information reaching the displaced in 2000. They recounted situations from polling stations in the Republika Srpska in which voters from the Federation were not listed on the final voter list and officials did not provide accurate information to correct the omission.

\footnotetext{
24 The OSCE notes that "[E]veryone will have the right to freedom of expression including the right to communication. This right will include freedom to hold opinions and to receive and impart information and ideas without interference by public authority and regardless of frontiers" (Conference for Security and Cooperation in Europe 1990, 8).

${ }^{25}$ Minority return has had a positive effect on political campaigning: during the 2002 elections, cross-entity campaigning increased. Parties targeting Bosnian Serb voters that generally only campaigned in the Republika Srpska, began to campaign in the Federation as well. The OSCE suggested that these campaigns began in order to provide information to minority returnees (OSCE/ODIHR 2003).
} 
The passage of the Permanent Election Law codified the responsibility of information dissemination. According to the law, the Election Commission of Bosnia-Herzegovina is required to "publicize all Rules of Procedure, Regulations and election results, voter information and all other information necessary for the implementation of this law and all electoral laws, in the Official Gazettes and the media, both inside and outside Bosnia and Herzegovina as appropriate. . . " $(2001,5)$. In practice, however, refugees and IDPs still found themselves receiving incorrect information or no information at all. In 2004, absentee polling stations were in charge of verifying the absentee voting process; not a single absentee envelope was rejected. However, once the ballots were taken from the envelopes and examined, 9.7 percent were deemed invalid. The OSCE calls this "an extremely high percentage" $(2005,21)$ and suggests that this problem calls into question the quality of voter education programs (2005). In other words, lack of information about how to cast an absentee ballot contributed to the rejection of almost 10 percent of these ballots.

\section{Security}

One of the most important considerations in post-conflict elections is voter security. Postconflict societies can be fragmented or polarized with variation in attitudes towards democracy, compromise, and tolerance. Moreover, as was the case in Bosnia, ex-combatants and war criminals may be active in the community. Refugees and IDPs are particularly vulnerable and must perceive that they will be able to safely cast ballots to ensure participation in elections. ${ }^{26}$ The security issue is particularly salient if a proper network of law enforcement and peacekeeping has not been arranged to protect minorities or the displaced. ${ }^{27}$

During the 1996 elections, the displaced in Bosnia who wished to return to and vote in their 1991 residences experienced significant problems related to limited freedom of movement (OSCE 1996b). As previously discussed, a central tenet of the DPA was that by election day, most displaced would have begun to return to their pre-war residences with the op- tion of voting in one's current residence to be used only in the most extreme circumstances. This commitment resulted in the provision of transportation to those who wished to vote at their "home" polling stations. For those who could not return, election administrators provided absentee polling stations on the border of the two entities and elsewhere.

Despite these considerations by the OSCE, refugees and IDPs still faced barriers to their freedom of movement. Because a climate of security had not been achieved by election day, the OSCE told voters wanting to cross the Inter-Entity Boundary Line to vote that their security could not be guaranteed (1996a). The OSCE provided secure transportation along nineteen routes for those who wished to cross the boundary, but only a limited number of displaced persons chose this option. Officials hypothesized that voters who in July declared that they would return to vote (rather than vote by absentee ballot) became increasingly fearful about crossing the border-ultimately resulting in their decision not to traverse it on election day. However, the OSCE conceded that a lack of information concerning their provision of transportation could have also been to blame (1996a). The OSCE's second statement on the elections in 1996 suggested that for the 1997 elections a concerted effort had to be made to increase the international presence and security measures in order for a proper environment to exist in which to hold the elections (1996b).

${ }^{26}$ Election standards documents specifically denounce any kind of violence in conjunction with elections. The Association of Central and Eastern European Election Officials points out that citizens should not be compelled to vote a certain way due to intimidation or violent threat by others. It goes further to condemn violence specifically, stating that the members agree "to take measures to ensure that the election campaign is conducted in the conditions of public safety and calmness, to thwart any attempts at violence, intimidation or similar actions or threats in the course of elections" $(2002,1)$.

27 The International Crisis Group argued that Bosnia was not ready to pursue elections in 1996 for many of the above security reasons. Their report indicates that freedom of movement was almost non-existent due to the threat of violence against those who ventured into areas where they were an ethnic minority. The report also found it particularly disturbing that parties in support of known war criminals such as Radovan Karadzic were allowed to compete in elections and support the war criminals (1996a). 
Although security at normal polling stations on election day in 1996 was deemed satisfactory, security at absentee stations used by refugees and IDPs was poor due to inadequate crowd control and general voter safety (OSCE 1996a). The poor security situation was exacerbated by disorganization manifested by inaccurate voter lists and lack of ballots or other necessary materials. Inadequate security caused some stations to shut down early or not to open at all (OSCE 1996a).

Resolution of the security problem has come slowly. With the passage of the Permanent Election Law, more emphasis was placed on penalizing those parties and individuals seeking to incite violence or manipulate the vote in other ways. ${ }^{28}$ Subsequently, security and freedom of movement improved. The OSCE commented that in the 2004 elections, "Civil and political rights were generally respected by the authorities at all levels. ... Displaced persons were free to return to their pre-war municipalities both to register and to vote" $(2005,11)$. In 2006, the only threats to security were the use of inflammatory nationalist rhetoric by some of the parties. The Serbian Radical Party was penalized the maximum amount for a campaign song using nationalism to incite violence and hatred. Although these inflammatory instances occurred, the OSCE report did not note subsequent violence (2006).

Lastly, the question of ballot security is also of particular concern to refugees and IDPs. Some scholars have suggested that refugees and IDPs can become targets if election officials count the absentee ballots of refugees and IDPs separately from other votes (Fischer and Grace 2003). According to the Provisional Election Commission's Rules and Regulations for the 1996 elections, refugee and absentee ballots were to be mixed with the ordinary vote before counting. While this policy should minimize risk if implemented properly, other problems arose concerning security of the vote. Absentee voters in Bosnia's 1998 elections were particularly fearful about casting their votes using absentee ballots due to the ballot's faulty design. Absentee ballots were printed on both sides of the paper so that the voter had no way of concealing his or her identity and vote from election administrators (OSCE 1998). Finally, in several elections, Bosnia experienced delays in the counting of absentee ballots which resulted in the delay of the announcement of the results of the elections. Delays potentially undermine the legitimacy of the elections and can result in violence and instability. ${ }^{29}$ By the 2006 general election, however, the security situation had stabilized and reports of voter intimidation or a tense environment in polling stations were limited (OSCE 2007).

\section{Manipulation}

Refugees and IDPs are often subject to manipulation based on their vulnerability, their dependency on states or organizations, and their unique position of not having a permanent residence. By far, the most controversial topic in refugee and IDP voting in Bosnia has been allowing refugees and IDPs to vote in their future residences in the case of refugees, and their current residences in the case of IDPs. This provision opened the elections up to manipulation as various groups attempted to convince refugees and IDPs to vote in a certain municipality through intimidation and coercion. ${ }^{30}$

Despite standards calling for elections free of intimidation or undue influence over voters, substantial evidence of manipulation emerged

${ }^{28}$ Chapter 6 and Article 7.3 of the Permanent Election Law detail what actions by political parties and candidates are prohibited and in case of violation, the complaint and penalty process.

29 The 2006 elections again experienced delays in the count of absentee, tendered, mobile, and out-of-country ballots-all methods used by refugee and IDP voters. At the time of the preliminary report by the OSCE, the count was not complete and expected to take days. The OSCE predicted this delay would affect public confidence in the election (2006).

30 The Association of Central and Eastern European Election Officials addresses this issue of intimidation and coercion in its draft document on election standards. It states, "Participation of a citizen in elections shall be free and voluntary. Nobody shall influence a citizen to compel him to participate or not to participate in elections and/or electoral actions (procedures). Nobody shall compel a voter to vote for or against any definite candidate (candidates), any definite list of candidates of a political party (coalition) or prevent a voter from freely expressing his will. No voter shall be compelled by anybody to declare how he intends to vote or has voted. It shall not be allowed to gather and/or publish (disseminate) personal information about voters who have or have not taken part in the voting. ... " $(2002,1)$. 
in Bosnia's post-war elections. In 1996, IDPs were specifically targeted for coercion; most of the observed intimidation involved Serbs from the Republika Srpska encouraging Serb IDPs to register to vote in their current residence inside the Republika Srpska or to register in a future residence inside the Republika Srpska (International Crisis Group 1996b). Resident Serbs hoped to secure an absolute Serb majority in the entity and a very small Serb constituency in the Federation. According to the International Crisis Group's statement on the 1996 elections, this manipulation went unpunished by the electoral commission (1996b). The OSCE's final statement on the 1996 elections mentions nothing of this manipulation, only citing evidence of invalid ballots that may have been due to deliberate spoiling (1996b).

By the 1997 municipal elections, the problem of coercing IDPs had been brought to the attention of OSCE observers. The OSCE attempted different measures to prevent this type of manipulation, including raising the standards for documents required for registration. As already noted in the section on procedures, the OSCE acknowledged that this measure may have disenfranchised some refugees and IDPs who did not have access to the extensive list of documents required for them to register (1997a). The OSCE also attempted to make the Voter Registration Centers ethnically mixed to avoid coercion of certain ethnicities to vote in a specific municipality. While this goal was achieved in the Federation and helped to limit manipulation, the Voter Registration Centers in the Republika Srpska remained Serb-dominated, resulting in the intimidation of displaced Serbs to register to vote in certain municipalities (OSCE/ODIHR 1997a).

Another harmful technique used to manipulate the elections was withholding aid meant for the displaced until they agreed to register or vote in a certain location. Refugees residing in the Federal Republic of Yugoslavia were the most likely to experience this kind of manipulation. However, the OSCE observed attempts at manipulation in both Bosnia and the Federal Republic of Yugoslavia during the 1998 elections. The OSCE's final statement on the 1998 elections reports that those who did not register to vote in the municipalities preferred by
Serbian $^{31}$ authorities were refused certain services. For instance, in order to register their children for school or to buy a car, the refugees would be requested to present their voter registration slip. If they did not have one, they were refused these opportunities (1998).

Refugees in Croatia experienced different forms of manipulation, due to the campaigning that took place inside the country. The problem was instigated less by Croatian authorities and more by the Croatian Democratic Union, a Croat nationalist party that was allowed unrestricted access to the refugee populations in Croatia. One claim against the party was that its representatives sent letters to thousands of Bosnians residing in Croatia soliciting their support and encouraging them to register to vote in the Bosnian election. Another allegation that surfaced was the party's commercials being allowed to run on Croatian television (OSCE 1998). These two acts violated the rules regarding campaigning in the Bosnian election laws and suggest that refugees and IDPs faced significant obstacles to their free participation in elections. Manipulation is a threat in any election; however, the participation of refugees and IDPs needs to be monitored closely, as the displaced are a particularly easy and attractive target.

The most effective measure taken by the OSCE was to punish parties that could be clearly identified as having a role in the manipulation of the displaced. The Electoral Appeals Sub-Commission was in charge of punishing the offending parties. This punishment most often consisted of striking candidates from party lists. According to the OSCE's final statement on the 1997 municipal elections, the most serious manipulation of registration occurred in Brcko and Zepce and intimidation of registrants was also penalized in the cities of Jajce and Caplina. Thirty-five candidates in total were struck from party lists-nineteen from the party list of the Croat Democratic Union,

\footnotetext{
31 The makeup of the Federal Republic of Yugoslavia, at that time, was similar to Bosnia in that it consisted of two primary political entities-Serbia and Montenegro. The Serbian entity was most often responsible for handling refugees from Bosnia and by extension was the most observed perpetrators of manipulation.
} 
eleven from the party list of the Serb Democratic Party, and two from the party list of the Party of Democratic Action (1997a). The manipulation of voter registration was experienced in both entities, with the most candidates struck from any party list being those of the main nationalist Bosnian-Croat party. While engaging in this sort of punishment provides a disincentive for parties who would manipulate the elections, it also punishes candidates who may or may not have been involved in the manipulation conducted by their parties.

The penalty process codified in 2001 was not amended in 2006. Indeed, it seems that on the whole, after the adoption of the Permanent Election Law, manipulation was not a serious problem. The final report on the 2002 general elections by the OSCE stated that "Remarkably, very few cases were reported of undue influence on voters or Polling Station Committee members" $(2003,19)$. The quality of elections has improved in Bosnia, with the 2006 elections - the first solely administered by Bosnian authorities-demonstrating "further progress" toward international standards (OSCE 2007, 1).

\section{CONCLUSIONS}

The experience of Bosnia's refugees and IDPs sheds light on the question of how to protect displaced voters in electoral laws. There are a few specific successes to take from the Bosnian experience. First, Bosnia, like other countries dealing with conflict-forced migrants, was forced to decide where to allow the displaced to vote. Allowing refugees and IDPs to choose the municipality in which they cast their vote gives them greater freedom and ultimately increases the likelihood of their participation. Second, Bosnia's Permanent Election Law was successful in detailing provisions that imposed penalties on those that occupy the homes of the displaced. If the displaced have a home to which to return, then the problem of creating an electoral scheme that protects the right to vote of someone without a home is rendered moot. Finally, the OSCE was more successful at managing elections and helping to create an electoral law that protected the voting rights of refugees and IDPs in Bosnia's elections than in most countries in which it has involved itself in post-conflict reconstruction. ${ }^{32}$ This experience points to the potentially beneficial role of external organizations in addressing the challenges facing displaced voters.

Despite these successes, Bosnia's experience also illustrates the need for safeguards in an electoral process that includes refugees and IDPs. It is necessary to create an electoral law that makes participation easy and manipulation by others hard, though this balance is not always easy to achieve. Remedies to problems with procedures, information, security, and manipulation will increase the ability for refugees and IDPs to take part in the political process. Their ability to freely participate is critically important to both the legitimacy of the democratic process and the resolution of their displacement.

The case of Bosnia is important because displacement is an on-going phenomenon. Elections in post-war Iraq included accommodations for "special" voters such as the military and police who were asked to vote before election day to be available for work during the elections. Moreover, out-of-country voting for hundreds of thousands of diaspora Iraqis was arranged in fourteen countries (International Mission for Iraqi Elections 2005). Despite these arrangements, details about accommodations for IDP voters are not mentioned in official reports. ${ }^{33}$ In the United States, voters displaced by Hurricane Katrina also faced many of the issues of procedural and logistical barriers to participation in mayoral and congressional elections. Bosnia's electoral history illustrates many of the complex and sometimes overwhelming obstacles to voters who are also refugees or IDPs. Yet, Bosnia's experience also points to potential solutions to the problem of enfranchising the displaced.

\footnotetext{
${ }^{32}$ A report by the Brookings Institution states that in the majority of countries in which the OSCE has been charged with elections observation, it has not paid close attention to the issue of IDP voting. (Mooney and Jarrah 2005). Whereas the example of the OSCE's actions in Bosnia should be the rule, it is actually the exception.

${ }^{33}$ No mention of IDP voting was made in either the International Mission for Iraqi Elections' election report on the January 2005 election or the election report on the December 2005 election.
} 


\section{WORKS CITED}

AIM Sarajevo. 2000. “Dossier: Election Law in B\&H.” AIM Press. February 9, 2000.

Association of Central and Eastern European Election Officials. 2002. "Draft Convention on Election Standards, Electoral Rights and Freedoms." Retrieved May 18, 2007, from <http://www.venice.coe.int/docs/2003/ CDL(2003)057-e.asp >.

Berinsky, Adam J., Nancy Burns, and Michael W. Traugott. 2001. "Who Votes by Mail? A Dynamic Model of the Individual Consequences of Voting-By-Mail Systems." Public Opinion Quarterly. 65:178-197.

Black, Richard. 2001. "Return and Reconstruction in Bosnia-Herzegovina: Missing Link, or Mistaken Priority?" SAIS Review. 21(2): 177-199.

Bojkov, Victor D. 2003. "Democracy in Bosnia and Herzegovina: Post-1995 Political System and its Functioning." Southeast European Politics. 4(1):41-67.

Brady, Henry E., Michael Herron, Walter R. Mebane, Jr., Jasjeet S. Sekhon, Kenneth Shotts, and Jonathan Wand. 2001. "Law and Data: The Butterfly Ballot Episode." PS: Political Science and Politics. 34:59-69.

Brady, Henry et al. 2004. "Symposium: US ElectionsHow the Rules You Choose and the Way You Count Determine the Winners You Get." Perspectives on Politics. 2:489-549.

Bunce, Valerie. 1999. Subversive Institutions: The Design and the Destruction of Socialism and the State. Cambridge: Cambridge University Press.

Burwitz, Bernd. 2004. "The Elections in Bosnia-Herzegovina, October 2002." Electoral Studies. 23(2): 329-360.

Casperson, Nina. 2004. "Good Fences Make Good Neighbors? A Comparison of Conflict-Regulation Strategies in Postwar Bosnia." Journal of Peace Research. 41(5):569588.

Centers for Civic Initiatives and the NGO Network of BiH. 2000. "Preliminary Report Municipal Elections BiH April 2000." prepared for the National Democratic Institute, Washington D.C. Retrieved May 18, 2007, from <http://www.accessdemocracy.org/library/1049_ bo_municelect.pdf $>$.

Conference for Security and Cooperation in Europe. 1990. "Document of the Copenhagen Meeting of the Conference on the Human Dimension of the CSCE." Retrieved March 24, 2006, from <http://www.osce.org/ documents/odihr/1990/06/13992_en.pdf $>$.

Cousens, Elizabeth M. 2002. "From Missed Opportunities to Overcompensation: Implementing the Dayton Agreement on Bosnia." In Ending Civil Wars: The Implementation of Peace Agreements, eds. Stephen John Stedman, Donald Rothchild, and Elizabeth M. Cousens. Boulder: Lynne Rienner.

Daalder, Ivo H. 2000. Getting to Dayton: The Making of America's Bosnia Policy. Washington, D.C.: Brookings Institution Press.

Dahl, Robert. 2000. On Democracy. New Haven: Yale University Press.

Dahlman, Carl and Gearóid Ó Tuathail. 2005. "The legacy of ethnic cleansing: The international community and the returns process in post-Dayton Bosnia-Herzegovina." Political Geography. 24: 569-599.

Dayton Peace Accords. 1995. "The General Framework Agreement for Peace." Retrieved Sept. 15, 2006, from $<$ http://www.ohr.int/dpa/default.asp?content_id=3 $80>$.

Election Law of BiH. 2001. Translated from the original language by the OSCE Mission to Bosnia and Herzegovina Election/Implementation Department. Retrieved May 22, 2005, from < http://www.aeobih.com. ba/documents / election \%20law\%20-\%20eng\%20language.pdf $>$.

European Commission for Democracy through Law (Venice Commission). 2006. "Draft Law on Amendments to the Election Law of Bosnia and Herzegovnia." Opinion no. 372/2006. Retrieved March 26, 2006, from <http://www.venice.coe.int/docs / 2006/CDL-EL (2006)013-e.asp >.

Fischer, Jeff and Jeremy Grace. 2003. "Enfranchising Conflict-Forced Migrants: Issues, Standards, and Best Practices." Discussion Paper No. 2 prepared for the International Organization of Migration, Geneva. Retrieved May 18, 2007, from < http://www.geneseo.edu/ iompress/Archive/Outputs/Standards_Final.pdf $>$.

Goler, Jonathan A. and Edwin J. Selker. 2006. "Augmenting Voter Interfaces to Improve Accessibility and Performance." Retrieved May 23, 2007, from the Voting Technology Project: <http://www.vote.caltech. edu/reports/chi-abstract-golerselker.pdf $>$.

Graham, Paul. 2006. "Marginalized Voters and Groups with Special Needs." Web page prepared for Administration and Cost of Elections Project. Retrieved May 22, 2007 from <http://aceproject.org/ace-en/topics/ve/ ved $/$ ved $03 /$ ved $03 \mathrm{a} /$ ved $03 \mathrm{a} 03 /$ ? searchterm $=$ specia $1 \% 20$ voting\%20rights $>$.

Hall, Thad E. 2003. "Public Participation in Election Management: The Case of Language Minority Voters." American Review of Public Administration. 33(4):407-422.

Herron, Michael C. and Jasjeet S. Sekhon. 2003. “Overvoting and Representation: An Examination of Overvoted Presidential Ballots in Broward and Miami-Dade Counties." Electoral Studies. 22:21-47.

International Crisis Group. 1996a. "Why the Bosnian elections must be postponed." ICG Bosnia Report No. 14. Retrieved March 31, 2006, from <http://www.crisisgroup.org/home/index.cfm?id=1504\&l=1>.

International Crisis Group. 1996b. "Elections in Bosnia \& Herzegovina." ICG Bosnia Report No. 16. Retrieved March 31, 2006, from <http://www.crisisgroup.org/ home $/$ index.cfm? $\mathrm{id}=1567 \& \mathrm{l}=1>$.

International Crisis Group. 1998. "Doing Democracy a Disservice: 1998 Elections in Bosnia-Herzegovina." Europe Report No. 42. Retrieved May 22, 2007, from $<$ http://www.crisisgroup.org/home/index.cfm? action $=$ login\&ref_id $=1511>$.

International Crisis Group. 2000. “Bosnia's November Elections: Dayton Stumbles." Europe Report No. 104. Retrieved May 22, 2007, from < http://www.crisisgroup. org $/$ home/index.cfm?id $=1569 \& l=1>$. 
International Mission for Iraqi Elections. 2005. "Evaluation of the Out-of-Country Voting Program for the January 30, 2005, Iraqi Elections." Retrieved April 22, 2006, from < http://www.imie.ca/rep_OCV.html>.

Kaldor, Mary. 1999. New and Old Wars: Organized Violence in a Global Era. Cambridge: Polity Press.

Knack, Stephen and Martha Kropf. 2003. "Voided Ballots in the 1996 Presidential Election: A County-Level Analysis." Journal of Politics. 65:881-897.

Lacy, Brett. 2004. "Building accountability, legitimacy, and peace: refugees, internally displaced persons, and the right to political participation." Paper prepared for the International Foundation for Elections Systems, Washington, D.C. Retrieved Jan. 12, 2006, from $<$ http://www.ifes.org/publication/024df7ba77f3bae8 7709edc67743fba8/08_04_Hybl_BrettLacy.pdf $>$.

Lippman, Peter. 2006. "Bosnia's "Historic" Elections: The Usual Tensions, Plus a Seed of Hope." The Washington Report on Middle East Affairs. 25(9):32-33.

Manning, Carrie. 2004a. "Armed Opposition Groups into Political Parties: Comparing Bosnia, Kosovo and Mozambique." Studies in Comparative International Development. 39(1):54-76.

Manning, Carrie. 2004b. "Elections and Political Change in Post-War Bosnia and Herzegovina." Democratization. 11(2): 60-86.

Manning, Carrie and Miljenko Antic. 2003. "The Limits of Electoral Engineering." Journal of Democracy. 14(3): 45-59.

March, James P. and Johan P. Olsen. 1995. Democratic governance. New York: Free Press.

McGaley, Margaret and J. Paul Gibsen. 2003. "Electronic Voting: A Safety Critical System." Final Year Project Report. NUI Maynooth Department of Computer Science.

Mercurio, Bryan. 2003. "Discrimination in electoral law: Using technology to extend the secret ballot to disabled and illiterate voters." Alternative Law Journal. 28(6): 272-276.

Mooney, Erin and Balkees Jarrah. 2005. “Displaced and Disenfranchised: Internally Displaced Persons and Elections in the OSCE Region." Ethnopolitics. 4(1): 29-48.

Morton, Jeffrey S., R. Craig Nation, Paul Forage, and Stefano Bianchini (eds). 2004. Reflections on the Balkan Wars: Ten Years After the Break Up of Yugoslavia. New York: Palgrave Macmillan.

National Democratic Institute for International Affairs. 1996. "Bosnia and Hercegovina: Strengthening Political Parties." NDI Reports. Retrieved May 26, 2007, from $<$ http://www.accessdemocracy.org/showdoc.asp?lang $=1 \& \mathrm{id}=\{8128489 \mathrm{~F}-\mathrm{D} 2 \mathrm{C} 7-11 \mathrm{D} 4-\mathrm{B} 41 \mathrm{C}-00 \mathrm{D} 0 \mathrm{~B} 7 \mathrm{C} 8 \mathrm{CF} 21\}>$.

Office of the High Representative. 2000. "19\% of the property claims resolved throughout $\mathrm{BiH}$." Press release December 21, 2000. Retrieved March 27, 2006, from $<$ http://www.ohr.int/ohr-dept/presso/pressr/default. asp?content_id $=4172>$.

Organization for Security and Cooperation in Europe and the Office for Democratic Institutions and Human Rights. 2002. "International Standards and Commitments on the Right to Democratic Elections: A Practical Guide to Democratic Elections Best Practice." OSCE/
ODIHR Draft Paper, submitted to working session on election standards at OSCE Human Dimension Implementation Meeting. Retrieved March 22, 2006, from <http://www.osce.org/item/1691.html>.

Organization for Security and Cooperation in Europe and the Office for Democratic Institutions and Human Rights Election Observation Mission. 1996a. "Preliminary Statement on the elections in Bosnia and Herzegovina on 14 September 1996." Retrieved May 21, 2005, from < http://www.osce.org/item/1367.html >.

Organization for Security and Cooperation in Europe and the Office for Democratic Institutions and Human Rights Election Observation Mission. 1996b. "Second Statement on Elections in Bosnia and Herzegovina on 14 September 1996." Retrieved May 21, 2005, from <http://www.osce.org/item/1355.html>.

Organization for Security and Cooperation in Europe and the Office for Democratic Institutions and Human Rights Election Observation Mission. 1997a. "Final report on the municipal elections in Bosnia and Herzegovina, 13-14 September 1997." Retrieved May 21, 2005, from <http://www.osce.org/item/1369.html>.

Organization for Security and Cooperation in Europe and the Office for Democratic Institutions and Human Rights Election Observation Mission. 1997b. "Preliminary Statement on Municipal Elections in Bosnia and Herzegovina, 13-14 September 1997." Retrieved May 21, 2005, from <http://www.osce.org/item/1365. html>.

Organization for Security and Cooperation in Europe and the Office for Democratic Institutions and Human Rights Election Observation Mission. 1998. "Final report on the elections in Bosnia and Herzegovina, 1213 September 1998." Retrieved May 21, 2005, from <http://www.osce.org/item/1371.html>.

Organization for Security and Cooperation in Europe and the Office for Democratic Institutions and Human Rights Election Observation Mission. 2003. "Final Report on the General Elections in Bosnia and Herzegovina, 5 October 2002." Retrieved May 21, 2005, from <http://www.osce.org/item/1361.html >.

Organization for Security and Cooperation in Europe and the Office for Democratic Institutions and Human Rights Election Observation Mission. 2005. "Final Report on Municipal Elections in Bosnia and Herzegovina, 2 October 2004." Retrieved May 21, 2005, from $<$ http://www.osce.org/item/4243.html $>$.

Organization for Security and Cooperation in Europe and the Office for Democratic Institutions and Human Rights Election Observation Mission. 2006. "Preliminary Statement on General Elections in Bosnia and Herzegovina, 1 October 2006." Retrieved February 1, 2007, from <http://www.osce.org/item/20826.html>.

Organization for Security and Cooperation in Europe and the Office for Democratic Institutions and Human Rights Election Observation Mission. 2007. "Final Report on General Elections in Bosnia and Herzegovina, 1 October 2006." Retrieved February 15, 2007, from <http://www.osce.org/item/23206.html>. 
Pugh, Michael and Margaret Cobble. 2001. "Non-Nationalist Voting in Bosnian Municipal Elections: Implications for Democracy and Peacebuilding." Journal of Peace Research. 38(1):27-47.

Roberts, Hannah. 2003. "FMO Research Guide: Forced Migration and Electoral Participation." Retrieved Feb. 22, 2006, from <http://www.forcedmigration.org/ guides $/ \mathrm{fmo} 020 / \mathrm{fmo020}$.pdf $>$.

Sobyanin, A. A. and V. G. Sukhovolskiy. 1995. Demokratiya, ogranichennaya falsifikatsiyami: vybory i referendumy $v$ Rossii v 1991-1993 gg. Moscow: Project Group for Human Rights.

Southwell, Priscilla L. and Justin Burchett. 1997. "Survey of Vote-by-Mail Senate Election in the State of Oregon." PS: Political Science \& Politics. 30(1): 53-58.

Tomz, Michael and Robert P. Van Houweling. 2003. "How Does Voting Equipment Affect the Racial Gap in Voided Ballots?" American Journal of Political Science. 47:46-60.

United Nations Office for the Coordination of Humanitarian Affairs. 1998. "Guiding Principles on Internal Displacement." Retrieved Feb. 22, 2006, from <http:// www.unhchr.ch/html/menu2/7/b/principles.htm\#* $>$.

United Nations Office of the High Commissioner for Human Rights. 1951. "Convention Relating to the Status of Refugees." G.A. res. 429 (V). entered into force 22 April,
1954. Retrieved Feb. 22, 2006, from <http://193.194. 138.190/html/menu3/b/o_c_ref.htm $>$.

Wall, Alan. 2003. "Other Special Voting Arrangements." Web page prepared for the Administration and Cost of Elections Project. Retrieved May 18, 2007, from <http://aceproject.org/ace-en/topics/vo/voa/voa02/ voa $02 \mathrm{~g} /$ default $/$ ?searchterm $=$ special $\% 20$ needs $\% 20 \mathrm{vo}$ ters $>$.

Wand, Jonathan N., Kenneth W. Shotts, Jasjeet S. Sekhon, Walter R Mebane, Jr., Michael C. Herron, and Henry E. Brady. 2001. "The Butterfly Did It: The Aberrant Vote for Buchanan in Palm Beach County, Florida." American Political Science Review. 95:793-810.

Address reprint requests to: Erik S. Herron

Department of Political Science University of Kansas 1541 Lilac Lane Blake Hall Lawrence, KS 66044-3177

E-mail: sherron@kw.edu 